\title{
KAJIAN AWAL PEMANFAATAN PULP DARI LIMBAH KEMASAN ASEPTIK UNTUK PEMBUATAN SELULOSA ASETAT
}

\author{
Mahammad Khadafi ${ }^{1}$, Yuniarti P. Kencana \\ Balai Besar Pulp dan Kertas, \\ J1. Raya Dayeuhkolot no. 132, Bandung 40258, Indonesia \\ 1dafi86@yahoo.com \\ Diterima : 20 Agustus 2013, Revisi akhir : 25 November 2013, Disetujui terbit : 02 Desember 2013

\section{A PRELIMINARY STUDY OF THE USE OF PULP FROM ASEPTIC PACKAGING WASTE FOR CELLULOSE ACETATE}

\begin{abstract}
The use of aseptic packaging in the world is still increasing from year to year, this causes a new matter like midden. Recycling the aseptic packaging is one of the efforts to utilize this waste. The raw material used for cellulose acetate crystal can be obtained from recycling process of aseptic packaging waste. This can be possible because pulp from aseptic packaging contain $72 \%$ needle unbleached virgin pulp. The purpose of this reasearch is to diversify the use of aseptic packaging waste by improving the technology process of acetylation for making cellulose acetate crystal. Aseptic packaging pulp was tested for the parameters such as water content, ash content, holocellulose content, $\alpha$ cellulose content, lignin content, and hemicellulose content. This tested was used to know the eligibility of pulp for making cellulose acetate. The pulp was soaked with water and glacial acetic acid for swelling and conditioning. The acetylation process was done with adding glacial acetic acid and acetic acid anhydride in certain composition. Based on ASTM D 871-96 testing method, we obtained the optimum condition of acetyl content is $36.85 \%$ by adding $2.25 \mathrm{~mL}$ water and $35 \mathrm{~mL}$ acetic acid anhydride, whereas with the addition of $2.75 \mathrm{~mL}$ water and $30 \mathrm{~mL}$ acetic acid anhydride $28.28 \%$ acetyl content were obtained.
\end{abstract}

Keywords : aseptic packaging pulp, acetate cellulose, acetylation process, acetyl content

\begin{abstract}
ABSTRAK
Penggunaan kemasan aseptik yang meningkat dari tahun ke tahun, menimbulkan masalah baru berupa limbah. Salah satu upaya pemanfaatan limbah adalah melalui proses daur ulang. Hasil proses daur ulang ini diantaranya dapat dijadikan substitusi bahan baku produk derivat selulosa berupa selulosa asetat, karena limbah kemasan aseptik mengandung pulp virgin serat panjang $72 \%$. Tujuan dari penelitian ini adalah untuk diversifikasi penggunaan dan pemanfaatan limbah kemasan aseptik melalui proses daur ulang dan penguasaan teknologi proses asetilasi untuk produk selulosa asetat. Pulp kemasan aseptik diuji dengan parameter kadar air, kadar abu, kadar holoselulosa, kadar $\alpha$ selulosa, kadar lignin, dan kadar hemiselulosa untuk mengetahui apakah pulp kemasan aseptik memenuhi persyaratan untuk dibuat selulosa asetat. Perendaman pulp dilakukan dengan air dan asam asetat glasial, kemudian diperas untuk mengkondisikan pulp sebelum proses asetilasi. Proses asetilasi dilakukan dengan menambahkan asam asetat glasial dan asam asetat anhidrida dalam jumlah tertentu. Berdasarkan metode ASTMD 871-96 diperoleh kadar asetil optimal dari kristal selulosa asetat sebesar 36,85\% dengan penambahan air 2,25 mL dan asetat anhydrida $35 \mathrm{ml}$, sedangkan untuk penambahan asam asetat anhidrida $30 \mathrm{~mL}$ dan air $2,75 \mathrm{~mL}$ diperoleh kadar asetil 28,28\%.
\end{abstract}

Kata kunci : pulp kemasan-aseptik, selulosa asetat, asetilasi, kadar asetil 


\section{PENDAHULUAN}

Kemasan aseptik adalah kemasan yang didesain khusus agar produk makanan atau minuman yang dikemas terhindar dari berbagai kontaminan seperti bakteri. Oleh sebab itu, biasanya kemasan aseptik dibuat kedap udara. Kemasan aseptik dibuat berlapis-lapis, terdiri dari polietilen (23\%), kertas/karton $(72 \%)$, dan alumunium (5\%) (Anonim, 2013). Tujuan sistem pelapisan kertas karton dengan komponen plastik dan alumunium pada limbah kemasan aseptik adalah untuk menyempurnakan tingkat kekedapan udara dalam kemasan tersebut. Aluminium dipilih karena harganya lebih murah dibandingkan logam atau bahan kedap udara lainnya, selain karena aluminium ini ringan dan tidak mudah korosi (Zuben and Neves, 2004).

Pada tahun 2008 hingga 2010, penggunaan kemasan aseptik di Indonesia cenderung meningkat dari 21.000 menjadi 28.000 ton (Santosa, 2009). Limbah kemasan aseptik tersebut dapat menimbulkan masalah lingkungan. Peredaran kemasan aseptik di Indonesia mencapai 4 miliar kemasan setiap tahun atau sekitar 333 juta per bulan. Jumlah itu dipasok dari dua produsen kemasan aseptik yang ada di Indonesia yakni PT. Tetrapak dan Combibloc. Dari jumlah 4 miliar tersebut hanya sekitar 1\% limbah kemasan terserap ke industri besar daur ulang (Rini, 2013). Salah satu upaya untuk memanfaatkan sampah tersebut adalah melalui proses daur ulang. Proses daur ulang limbah kemasan aseptik ini dapat dijadikan substitusi bahan baku salah satu produk derivat selulosa. Mengingat limbah kemasan aseptik bekas memiliki kandungan pulp virgin serat panjang sebanyak 72\% (Falconer dkk., 1995).

Pulp serat panjang yang diperoleh dari proses daur ulang limbah kemasan aseptik dapat dijadikan bahan baku alternatif produk derivat selulosa yaitu selulosa asetat teknis. Selain itu, diharapkan dapat meningkatkan nilai tambah limbah tersebut. Bidang penelitian yang sangat mendasar bagi perkembangan teknologi pembuatan selulosa asetat dan sangat tergantung dari bahan bakunya. Bahan baku polimer alam yang biasanya digunakan adalah pulp dissolving.

Selulosa asetat merupakan golongan ester selulosa yang dimodifikasi untuk memperbaiki sifat fisik dan kimianya untuk keperluan tertentu. Selulosa asetat dihasilkan dari selulosa melalui tahap aktivasi dengan asam asetat glasial dan tahap asetilasi dengan anhidrida asetat. Kadar asetil untuk selulosa asetat yang ada di pasar umumnya memiliki derajat substitusi gugus asetil 1,7 hingga 3 yaitu dengan persentasi derajat asetilasi 30-44\% (Kirk dan Othmer, 1993). Proses pembuatan selulosa asetat terdiri dari tahapan perendaman, asetilasi, hidrolisis, kristalisasi, pencucian dan pengeringan. Asetilasi pada selulosa merupakan reaksi subtitusi gugus hidroksil dengan gugus asetil. Asetilasi dapat dilakukan dengan amida, ester, anhidrida karboksilat, dan halida asam. Namun, amida dan ester bereaksi sangat lambat sedangkan halida asam reaktivitasnya sangat tinggi. Oleh karena itu, umumnya dipilih anhidrida asetat karena menghasilkan rendemen yang baik (Wafiroh, 2004).

Perubahan utama yang diharapkan dengan penambahan gugus asetil pada selulosa adalah sifat kelarutannya serta sifat fisik dari selulosa asetat hasilmodifikasi. Selulosa asetat mempunyai nilai komersial cukup tinggi karena selulosa asetat memiliki beberapa keunggulan diantaranya karakteristik fisik dan optik yang baik sehingga banyak digunakan sebagai serat untuk tekstil, filter rokok, substitusi bahan plastik biodegradable, film fotografi, lak, pelapis kertas dan membran, serta kemudahan dalam pemrosesan lebih lanjut (Kiyose, 1998). Selulosa asetat dapat larut pada berbagai pelarut bergantung kadar asetilnya. Selulosa asetat dengan kadar asetil 15-20\% larut dalam air, 24-32\% larut dalam 2-metoksimetanol, $37-42 \%$ larut dalam aseton, serta untuk kadar asetil $\geq 43 \%$ larut dalam diklorometan (Kirk dan Othmer, 1993).

Pada penelitian ini dilakukan pembuatan selulosa asetat dari limbah pulp kemasan aseptik. Hal ini dilakukan untuk diversifikasi pemanfaatan limbah kemasan aseptik sebagai bahan baku pembuatan produk derivat selulosa yaitu berupa selulosa asetat

\section{BAHAN DAN METODE}

Bahan yang digunakan pada penelitian ini adalah pulp hasil daur ulang limbah kemasan, asam asetat glasial merck sebagai pelarut, anhidrida asam asetat (AAH) (merck) sebagai prekursor pembentuk gugus asetat pada molekul selulosa, asam sulfat merck sebagai katalisator dan akuades sebagai reagen penghidrolisis. 


\section{Pengujian Parameter Bahan Baku Pulp Kemasan Aseptik}

Bahan baku berupa pulp hasil pemisahan dari limbah kemasan aseptik dilakukan pengujian berupa kadar air, kadar abu, kadar alfa selulosa, kadar hemiselulosa dan kadar holoselulosa. Pengujian kadar air dilakukan berdasarkan pada SNI 08-7070-2005 (SNI, 2005), kadar abu dari pulp mengacu pada SNI 14-1031-1989 (SNI, 1989), kadar alfa selulosa dan hemiselulosa mengacu pada SNI 0444:2009 (SNI, 2009) dan selanjutnya kadar holoselulosa mengacu pada SNI 14-1032-1989 (SNI, 1989). Gugus fungsi dianalisis menggunakan Fourier Transform Infra Red (FTIR)

\section{Pembuatan Selulosa Asetat dari Limbah Pulp Kemasan Aseptik}

Perlakuan awal pembuatan selulosa asetatadalah merendam pulp limbah kemasan aseptik kedalam air dengan perbandingan berat 1:2 terhadap berat kering pulp sebagai bahan baku. Kemudian pulp direndam dalam asam asetat glasial sehingga diperoleh pulp hasil perendaman dengan perbandingan berat 1:3 dari berat kering awal pulp. Pada proses asetilasi dilakukan pencampuran bahan baku pulp hasil perendaman ditambahkan pelarut asam asetat glasial dan asam sulfat pekat. Proses asetilasi ini berlangsung pada kondisi tertutup menggunakan labu leher tiga dan pengadukan konstan pada 250 rpm. Campuran diaduk selama 1 menit, $30^{\circ} \mathrm{C}$ dalam waterbath, kemudian ditambahkan asam asetat anhidrida dengan variasi 30 dan $35 \mathrm{~mL}$ per 30 gram berat basah dari pulp limbah kemasan aseptik hasil perendaman dari 10 gram berat kering pulp limbah kemasan aseptik. Campuran diaduk $250 \mathrm{rpm}$ selama 1 jam dan $30^{\circ} \mathrm{C}$. Setelah asetilasi dilanjutkan dengan proses hidrolisis dengan menambahkan air, asam asetat glasial, dan asam asetat encer sisa perasan pada perlakuan awal. Proses hidrolisis ini dilakukan dengan penambahan variasi volume air 2,25; 2,50 dan 2,75 mL. Campuran diaduk $250 \mathrm{rpm}$ selama 30 menit pada $30^{\circ} \mathrm{C}$. Pembentukan kristal selulosa asetat dilakukan dalam air yang diberi wadah dengan menuangkan sedikit demi sedikit cairan hasil hidrolisa lalu diaduk cepat pada temperatur kamar. Kristal selulosa asetat yang terbentuk kemudian dicuci dengan air dan dinetralkan dengan penambahan $\mathrm{NaOH}$. Setelah itu kristal selulosa asetat dikeringkan pada $60^{\circ} \mathrm{C}$ dan digerus dengan mortar lalu disaring dengan ukuran saringan 100 mesh. Alur proses pembuatan selulosa asetat dapat dilihat pada Gambar 1.

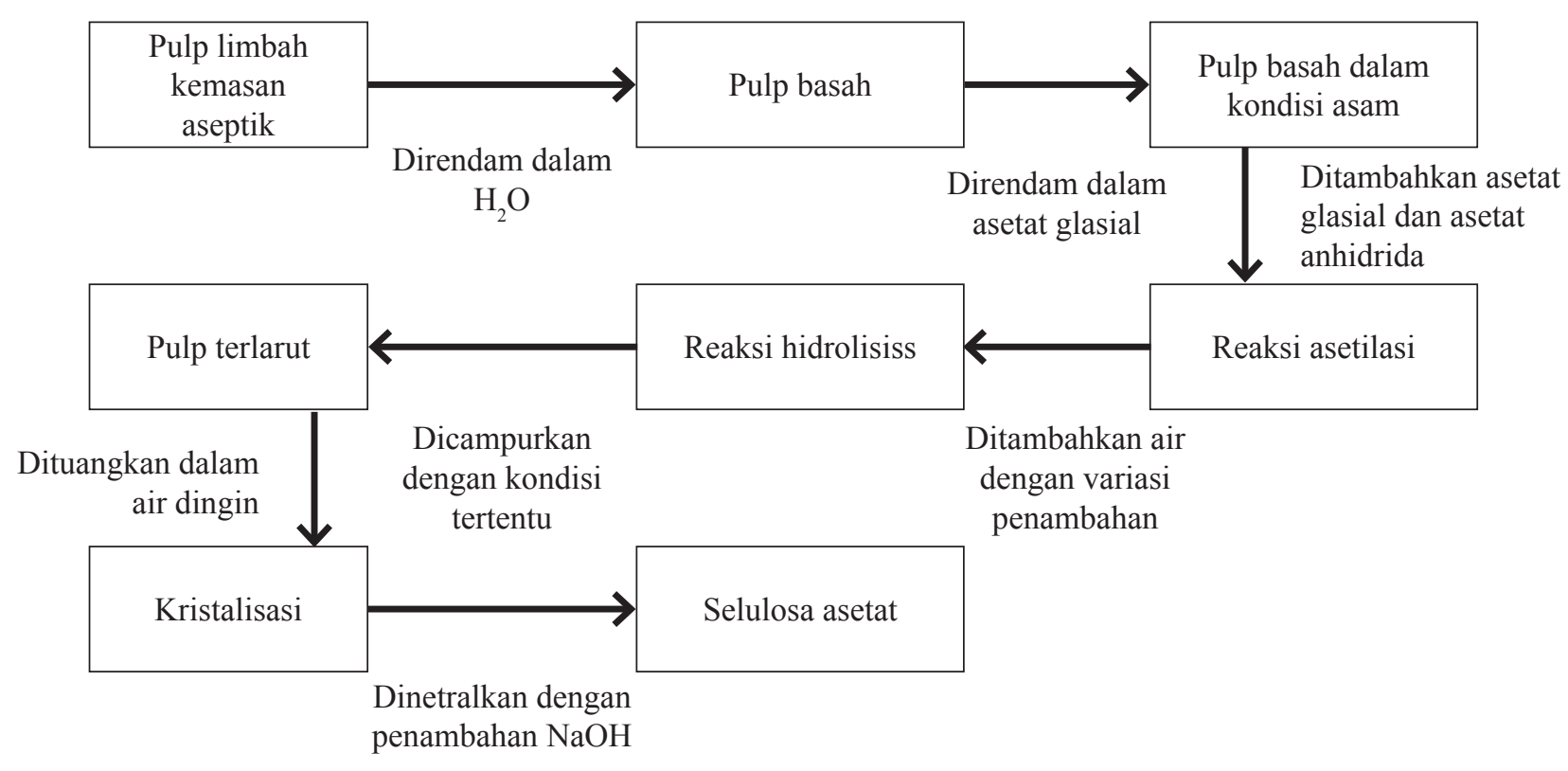

Gambar 1. Diagram Alir Proses Pembuatan Kristal Selulosa Asetat Dari Pulp Limbah Kemasan Aseptik 


\section{Pengujian Kadar Asetilasi dari Kristal Selulosa Asetat}

Pengujian kadar asetil dilakukan berdasarkan metode ASTM D 871-96. Sampel kristal selulosa asetat sebanyak \pm 1 gram berat kering ditimbang dan dipindahkan ke dalam Erlenmeyer dan ditambahkan pelarut alkohol 70\% sebanyak $40 \mathrm{ml}$ kemudian dipanaskan $50-60^{\circ} \mathrm{C}$ selama 30 menit. Selanjutnya $40 \mathrm{~mL}$ larutan $\mathrm{NaOH} \quad 0,5 \quad \mathrm{~N}$ ditambahkan dan dipanaskan $50-60^{\circ} \mathrm{C}$ selama 15 menit. Erlenmeyer ditutup rapat dengan aluminium foil dan diaduk pada suhu ruang sehingga kristal selulosa asetat swelling. Setelah dingin campuran ditetesi dengan indikator phenolfthalein lalu dititrasi secara asam - basa dengan larutan $\mathrm{HCl}$ $0,5 \mathrm{~N}$ yang telah distandarisasi. Titrasi dilakukan untuk Erlenmeyer blanko dan sampel dilanjutkan dengan perhitungan persen asiditas sebagai asam asetat bebas. Perhitungan dilakukan berdasarkan dengan Persamaan 1 (ASTM, 1991). Perhitungan kadar asetil dapat dilihat pada persamaan (1).

Kadar asetil $(\%)=((\mathrm{A}-\mathrm{B}) \mathrm{N} \times 0,06 \times 100) / \mathrm{W}$

Keterangan :

$\mathrm{A}=\mathrm{mL} \mathrm{NaOH}$ yang digunakan untuk titrasi contoh

$\mathrm{B}=\mathrm{mL} \mathrm{NaOH}$ yang digunakan untuk titrasi blanko

$\mathrm{N}=$ Normalitas larutan $\mathrm{NaOH}$

$\mathrm{W}=$ Berat contoh, gram

\section{HASIL DAN PEMBAHASAN}

\section{Limbah Kemasan Aseptik}

Berdasarkan hasil uji, pulp recycle dari limbah kemasan aseptik memiliki kadar abu yang tinggi jika dibandingkan dengan pulp kraft ataupun pulp dissolving karena pada pulp dissolving diperoleh kadar abu < 1\% (Emil dkk., 1954). Kadar abu yang tinggi ini diakibatkan banyaknya unsur silikat atau komponen anorganik yang terkandung dalam pulp karena banyaknya pengotor yang dihasilkan pada proses pembuatan selulosa asetat.

Hasil analisis komposisi bahan baku pulp limbah kemasan aseptik dapat dilihat pada Tabel 1. Pada tabel tersebut terlihat bahwa di dalam bahan baku pulp limbah kemasan aseptik terdapat kadar selulosa alfa yang cukup tinggi yaitu sebesar $65,20 \%$. Kadar selulosa alfa ini jika dibandingkan dengan karakteristik pulp dissolving tergolong rendah karena yang biasanya digunakan untuk bahan baku pembuatan selulosa asetat yaitu jenis pulp dengan kadar di atas 90\%. Kadar alfa selulosa yang rendah ini akan berakibat pada rendemen selulosa asetat yang dihasilkan menjadi sedikit (Victor dan Joseph, 1992).

Kadar sari yang diperoleh dari bahan baku pulp limbah kemasan aseptik cukup tinggi. Kadar holoselulosa dengan persentase $80,56 \%$ tergolong cukup tinggi dan sesuai dengan spesifikasi dari kadar holoselulosa pada pulp dissolving. Kadar lignin yang tinggi $11,98 \%$ sebagai pengotor pada pulp akan mengakibatkan banyak reaksi samping yang terbentuk saat bereaksi dengan asam asetat glasial. Walaupun demikian, diharapkan dengan kadar abu dan lignin yang cukup tinggi masih memenuhi persyaratan sebagai bahan baku selulosa asetat dan dapat dibuat selulosa asetat jenis teknis sesuai dengan persyaratan bahwa selulosa teknis memiliki persentase kadar asetil 24-32\% (Kirk dan Othmer, 1993).

\section{Pengaruh Jumlah Anhidrida Asam Asetat terhadap Kadar Asetil Selulosa Asetat dari Pulp Limbah Kemasan Aseptik.}

Tahap asetilasi merupakan tahap pembentukan selulosa triasetat dari hasil reaksi selulosa dengan asam asetat anhidrida, asam asetat, dan asam

Tabel 1. Hasil Analisis Komposisi Kimia Pulp Limbah Kemasan Aseptik (Emil dkk., 1954)

\begin{tabular}{lccc}
\hline \multicolumn{1}{c}{ Komposisi Kimia } & $\begin{array}{c}\text { Pulp limbah } \\
\text { kemasan aseptik (\%) }\end{array}$ & Pulp kraft (\%) & Pulp dissolving (\%) \\
\hline Kadar air & 4,26 & $70-80$ & $70-80$ \\
Kadar abu & 8,06 & $0-2$ & $0-2$ \\
Kadar selulosa alfa & 65,20 & $41-53$ & $87-96$ \\
Kadar lignin & 11,98 & $16-33$ & $<10$ \\
Kadar holoselulosa & 80,56 & $70-80$ & $80-90$ \\
Kadar hemiselulosa & 9,66 & $60-70$ & $<10$ \\
\hline
\end{tabular}


sulfat sebagai katalisator. Untuk mengetahui pengaruhnya pada proses asetilasi, pembuatan dilakukan dengan variasi volume anhidrida asam asetat dari 30 dan $35 \mathrm{~mL}$. Hal ini dilakukan dengan asumsi bahwa jumlah asam asetat anhidrida akan berpengaruh dalam pembentukan selulosa asetat primer (selulosa triasetat) (Yuniarti , 2002).

Gambar 2 menunjukkan bahwa meningkatnya penggunaan jumlah anhidrida asam asetat dari 30 dan $35 \mathrm{~mL}$ (jumlah $\mathrm{H}_{2} \mathrm{O}$ sebesar 2,25 mL), kadar asetil akan meningkat dari 28,28\% menjadi $36,85 \%$. Penggunaan jumlah anhidrida asam asetat 30 dan $35 \mathrm{~mL}$ (jumlah $\mathrm{H}_{2} \mathrm{O}$ sebesar 2,5 mL), kadar asetil akan meningkat dari 22,28\% menjadi $30,21 \%$. Sedangkan penggunaan jumlah anhidrida asam asetat dari 30 dan $35 \mathrm{~mL}$ (jumlah $\mathrm{H}_{2} \mathrm{O}$ sebesar 2,75 mL), kadar asetil akan meningkat dari 27,84\% menjadi 32,02\%. Penggunaan anhidrida asam asetat yang semakin meningkat akan memberikan kecenderungan kadar asetil meningkat cukup signifikan (Yuniarti, 2010). Jika penggunaan anhidrida asam asetat yang optimal maka selulosa diasetat yang terbentuk juga optimal, sehingga pada tahap hidrolisis selulosa diasetat yang terbentuk meningkat. Penggunaan jumlah anhidrida asam asetat 30 sampai $35 \mathrm{~mL}$ dan $\mathrm{H}_{2} \mathrm{O}$ 2,5 $\mathrm{mL}$ akan menurunkan kadar asetil. Pada penggunaan $\mathrm{H}_{2} \mathrm{O} 2,75 \mathrm{~mL}$, kadar asetil meningkat tidak signifikan.Hal ini disebabkan oleh tahap hidrolisis yang memerlukan jumlah $\mathrm{H}_{2} \mathrm{O}$ yang seimbang dengan jumlah anhidrida asam asetat. Pada hidrolisis dengan air yang lebih tinggi terjadi penurunan kadar asetil. Sehingga berpengaruh pada tahap hidrolisis dimana pada tahap ini selulosa triasetat yang akan terhidrolisis menjadi selulosa diasetat, terhambat pembentukannya.

Hasil optimal yang diperoleh, terjadi pada kondisi penggunaan anhidrida asam asetat sebanyak $35 \mathrm{~mL}$ dan kadar $\mathrm{H}_{2} \mathrm{O}$ sebanyak $2,25 \mathrm{~mL}$, kadar asetil yang dihasilkan cukup baik yaitu sebesar $36,85 \%$, dengan yield yang diperoleh sebanyak 17,50 gram atau 75,50\% dengan kadar air $9,47 \%$.

Kadar asetil selulosa asetat yang diperoleh kurang dari 37\%, sehingga dengan kadar selulosa asetat yang rendah termasuk ke dalam kategori selulosa asetat jenis teknis dengan tingkat kemurnian yang rendah (Kirk dan Othmer, 1993). Hal ini dapat terjadi karena didalam reaksi pembentukannya terdapat keseimbangan komposisi antara mol reaksi kedua reagen. Kurang keseimbangan mol reaksi tersebut menyebabkan kadar asetil yang diperoleh rendah. Cukup jauh jika dibandingkan dengan nilai kadar asetil selulosa asetat komersial yaitu sebesar $39,8 \%$.

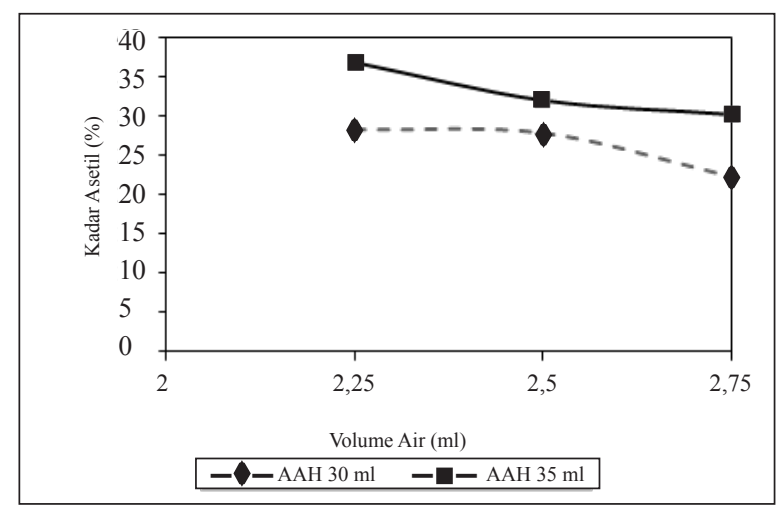

Gambar 2. Hasil Asetil Selulosa Asetat dari Pulp Limbah Kemasan Aseptik

Dari perhitungan mol reaksi, penggunaan reagen hidrolisis sebanyak $2,25 \mathrm{~mL}$ dan reagen asetilasi sebanyak $35 \mathrm{~mL}$ diperoleh mol reaksi reagen hidrolisis sebesar 0,23 mol sedangkan mol reaksi reagen asetilasi sebesar $0,64 \mathrm{~mol}$, sehingga rasio mol reaksi kedua reagen diperoleh sebesar 0,36. Rasio mol reaksi ini, jika dibandingkan dengan rasio mol reaksi yang diperkirakan secara reaksi kimia murni (stoikiometri) sebesar 0,37 hampir mendekati.

\section{Hasil Serapan Spektrum Inframerah Pulp Limbah Kemasan Aseptik dan Selulosa Asetat Pulp Limbah Kemasan Aseptik}

Hasil serapan spektrum inframerah pulp limbah kemasan aseptik dan selulosa asetat dapat dilihat pada Gambar 3 dan 4. Pada gambar tersebut terlihat perbedaan serapan pada panjang gelombang 1750 dan $1440 \mathrm{~cm}^{-1}$ yang mengindikasikan terbentuknya gugus asetil pada selulosa asetat.

Spektrum inframerah merupakan sifat-sifat khas senyawa-senyawa yang strukturnya sudah diketahui secara pasti. Spektrum infra merah selulosa asetat hanya suatu karakterisasi secara kualitatif. Spektrum inframerah selulosa asetat menunjukkan sejumlah pita serapan utama yang diperuntukan secara empiris bagi gugus fungsi didasarkan pada senyawa selulosa asetat. Hasil spektrum inframerah dapat dilihat pada Tabel 2.

Pengamatan terhadap spektrum inframerah menunjukkan perubahan tinggi dan besar puncak 


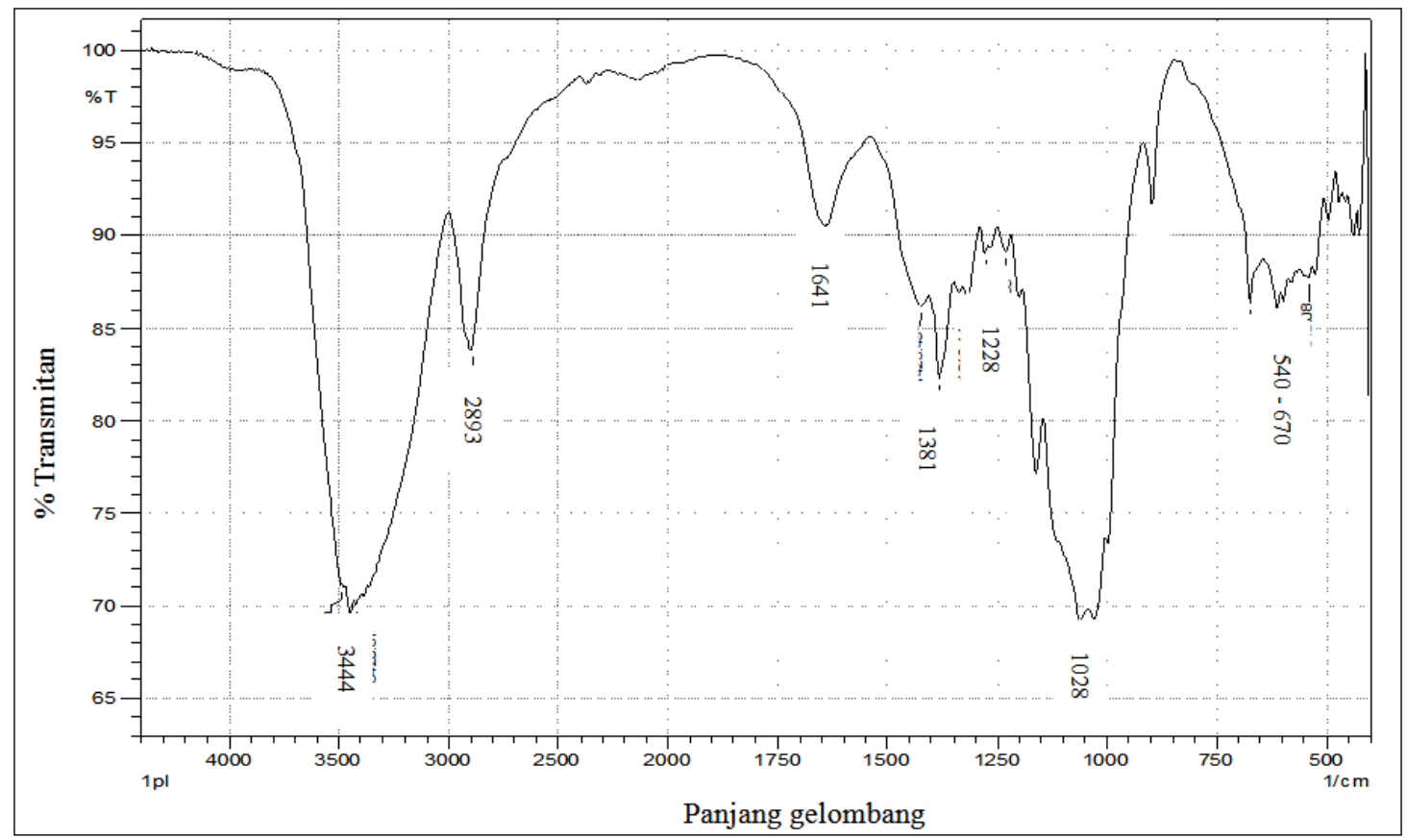

Gambar 3. Hasil Serapan Spektrum Inframerah Pulp Limbah Kemasan Aseptik

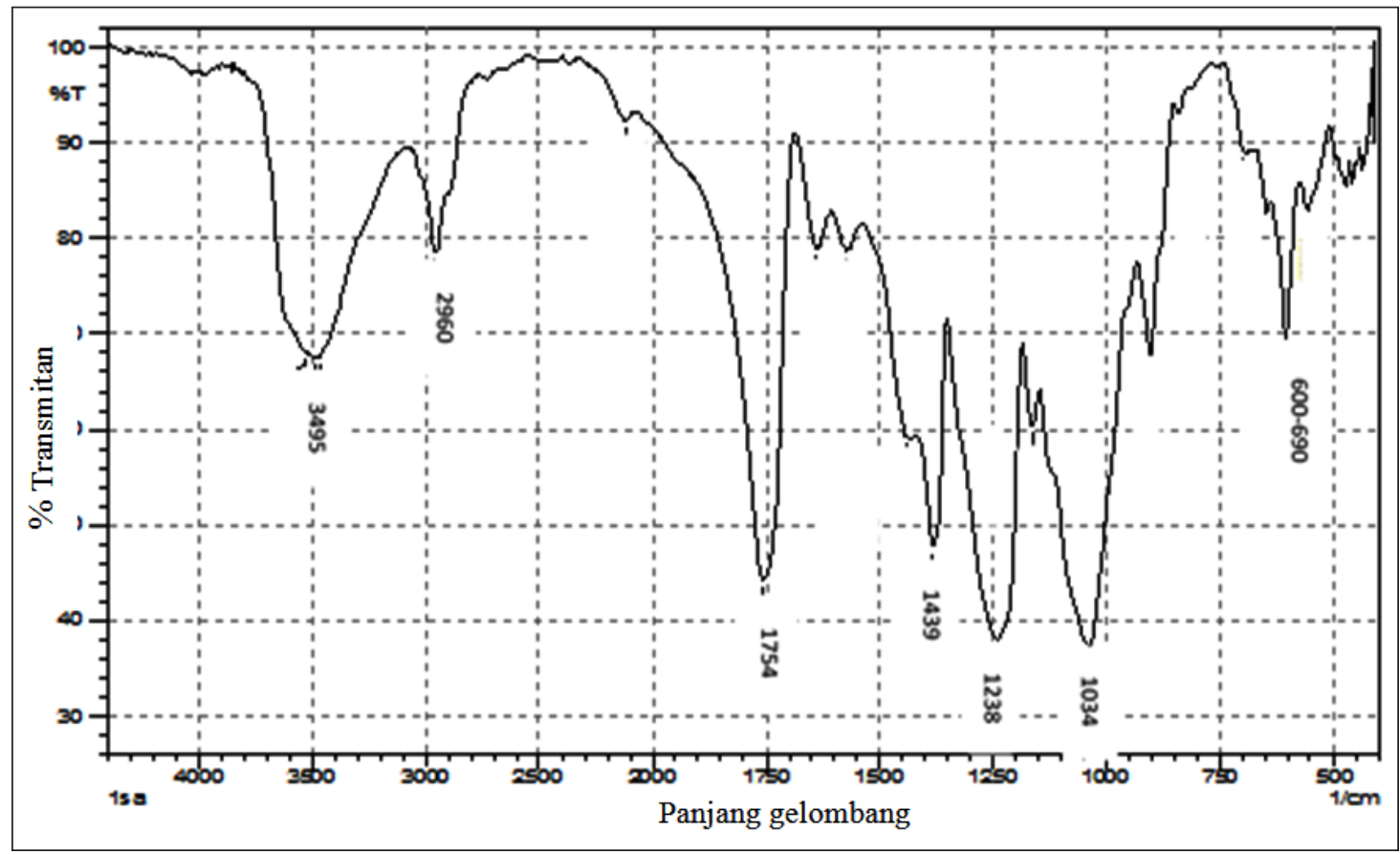

Gambar 4. Hasil Serapan Spektrum Inframerah Selulosa Asetat Pulp Limbah Kemasan Aseptik

serapan inframerah pada bilangan gelombang $3495,07 \mathrm{~cm}^{-1}$ untuk selulosa asetat dan $3444,92 \mathrm{~cm}^{-1}$ untuk bahan baku pulp kemasan aseptik, bilangan gelombang tersebut mengindikasikan gugus $\mathrm{OH}$ dari selulosa $\mathrm{CH}$ stretching telah mengalami perubahan (Victor dan Joseph, 1992). Serapan inframerah yang paling spesifik untuk selulosa asetat ini adalah timbulnya puncak serapan dengan bilangan gelombang $1754,29 \mathrm{~cm}^{-1}$. Hal ini menunjukkan adanya gugus $\mathrm{C}=\mathrm{O}$ dari gugus asetil, $-\mathrm{O}(\mathrm{C}=\mathrm{O}) \mathrm{CH}_{3}$. Adanya gugus asetil memberikan kesimpulan penting tentang unsur fungsional dalam struktur selulosa asetat (Yuniarti, 2010). Perubahan pada gugus fungsi 
Tabel 2. Hasil Spektra Inframerah Pulp Limbah Kemasan Aseptik dan Selulosa Asetat Pulp Limbah Kemasan Aseptik

\begin{tabular}{lcc}
\hline \multicolumn{1}{c}{ Gugus Fungsi } & $\begin{array}{c}\text { Pulp Limbah Kemasan } \\
\text { Aseptik } \\
\left(\mathrm{cm}^{-1}\right)\end{array}$ & $\begin{array}{c}\text { Selulosa Asetat Pulp Limbah } \\
\text { Kemasan Aseptik }\end{array}$ \\
\hline Gugus -OH & 3444,92 & 3495,07 \\
Gugus -CH- stretching metil/metilen & 2893,27 & 2960,78 \\
Vibrasi ulur C=O & 1641,45 & 1754,29 \\
Vibrasi kerangka aromatik & 1423,49 & 1572,01 \\
Vibrasi kerangka asimetrik & 1381,06 & 1439,89 \\
Gugus C-O stretching & 1228,32 & 1238,32 \\
Vibrasi ulur C-O alkohol & 1028,08 & 1034,83 \\
Vibrasi tekuk -CH- & 673,17 & 696,31 \\
\hline
\end{tabular}

dari selulosa, dengan sebagian gugus $\mathrm{OH}$ telah disubstitusi oleh gugus asetil $-\mathrm{O}(\mathrm{C}=\mathrm{O}) \mathrm{CH}_{3}$ dapat dikatakan bahwa proses asetilasi telah terjadi.

\section{KESIMPULAN}

Penelitian ini telah berhasil membuat kristal selulosa asetat dari pulp limbah kemasan aseptik dengan rendemen $75,50 \%$ pada kondisi proses temperatur $30^{\circ} \mathrm{C}$, kecepatan pengadukan $250 \mathrm{rpm}$ dan waktu reaksi 1 jam.

Kondisi dari proses pembuatan selulosa asetat dengan produk selulosa asetat teknisdiperoleh dengan penambahan asam asetat anhidrida $35 \mathrm{~mL}$ dan air 2,25 mL. Kadar asetil dari selulosa asetat yang dihasilkan adalah $36,49 \%$, kadar ini sesuai dengan persyaratan kadar asetil teknis dengan persentasi 35\% - 40\%.

\section{UCAPAN TERIMA KASIH}

Penulis mengucapkan terima kasih pada Kementerian Perindustrian yang telah membiayai penelitian ini melalui program riset DIPA tahun 2011. Ibu Rike Yudianti dari LIPI Bandung yang telah membantu penyusunan makalah ini. Serta kepada teknisi litkayasa Ibu Srihartini dan Bapak Endang yang telah membantu penelitian di laboratorium.

\section{DAFTAR PUSTAKA}

Anonim. 2013. Tetrapack Sustainability Report 2013. Tertrapak company. Tetrapak annual report.
ASTM. 1991. ASTM D871: Standard Methods of Testing Cellulose Acetate. Philadelphia: American Society for Testing and Materials.

Emil, O., Spurlin, Harold, M. 1954. Cellulose and Cellulose Derivatives Part II. Interscience Publisher, Inc: New York.

Falconer, J.L., Noble, R.D., Spery, D.P. 1995. Membrane Separation Technology, Principal and Application, Elsevier Science B.V, Amsterdam.

Kirk, R. E., Othmer, D. E. . 1993. Encyclopedia of Polimer Science and Technology. Interscience publisher. New york.

Kiyose. 1998. U.S. Patent No. 5990304 and Levenspiel, Industrial and Engineering Chemistry (IEC), vol. 40, (1500), New York.

Rini, Y. 2013. Industri Daur Ulang Sampah KemasanAseptik.http://www.solopos. com/2013/10/07/industri-daur-ulangsampah-indonesia-kaya-potensi-butuhpartisipasi-454409. Diakses tanggal 1 November 2013.

Santosa, L. 2009. Propek Daur Ulang Serat Panjang dari Kemasan Aseptik Bekas. Prosiding Seminar Teknologi Pulp dan Kertas: Membangun Inovasi Teknologi Pulp dan Kertas Untuk Menghadapi tantangan Global. Balai Besar Pulp dan Kertas, Kementerian Perindustrian, Bandung.

Standar Nasional Indonesia. 1989. SNI 14-10311989: Cara Uji Kadar Abu, Silika dan Silikat Dalam Pulp dan Kayu. Indonesia: Badan Standarisasi Nasional. 
Standar Nasional Indonesia. 1989. SNI 141032-1989: Cara Uji Kadar Sari (Ekstrak Alkohol Benzena dalam Pulp dan Kayu). Indonesia: Badan Standarisasi Nasional.

Standar Nasional Indonesia. 2005. SNI 087070-2005: Cara Uji Kadar Air Pulp dan Kayu Dengan Metode Pemanasan Dalam Oven. Indonesia: Badan Standarisasi Nasional.

Standar Nasional Indonesia. 2009. SNI 0444:2009 Cara Uji Kadar Selulosa Alfa, Beta dan Gamma. Indonesia: Badan Standarisasi Nasional.

Victor, A. H., Joseph, R. Z.1992. Acetic Acid and its Derivatives. CRC Press first edition, inc:New York.

Wafiroh, S. 2004. Pembuatan Membran Selulosa Asetat dari Pulp Abaca (Musa textilis). Tesis, Program Magister Kimia, Pasca Sarjana, ITB : Bandung.
Yuniarti, P. K. 2002. Penentuan kondisi optimum pembuatan selulosa asetat untuk bahan membran, Prosiding Seminar Teknolgi Pulp dan Kertas, Bandung.

Yuniarti, P. K.2010. Pemanfaatan cotton linter untuk produk selulosa asetat sebagai bahan membrane. Prosiding Seminar Teknologi Pulp dan Kertas. Bandung

Zuben, F., dan Neves, F.L. 2004. Recycling Of Aluminum and Polyethylene Present In Tetra Pak Packages. Seminário Internacional de reciclagem do Alumínio. Coletânia de Trabalhos. São Paulo. 